\title{
Educational Countermeasures of Chinese College Students' Media Literacy in the New Media Period
}

\author{
Wu Yi \\ Propaganda Department, Jiangsu University, Zhenjiang, People's Republic of China
}

\section{Email address:}

wuyi@ujs.edu.cn

\section{To cite this article:}

Wu Yi. Educational Countermeasures of Chinese College Students' Media Literacy in the New Media Period. Science Journal of Education. Vol. 5, No. 5, 2017, pp. 192-195. doi: 10.11648/j.sjedu.20170505.11

Received: June 26, 2017; Accepted: July 6, 2017; Published: August 1, 2017

\begin{abstract}
This paper analyzes the present situation of college students' media literacy in the new media environment, explains the external and internal causes of the lack of media literacy and puts forward four suggestions from the university level. Finally, the article draws a conclusion: The University has the responsibility to improve the college students' media literacy through standardized, systematic and practical educational activities.
\end{abstract}

Keywords: New Media, College Students, Media Literacy, Education Countermeasures

\section{Introduction}

Living in the media environment where challenges and contradictions, knowledge and temptation, political confrontation and interest competition coexist, only those who have media literacy can become a qualified citizen with active participation consciousness. They can actively use the media and produce media products while they have the subjective consciousness and independent thinking ability in the face of the ubiquitous media message. Media literacy is the ability of people to understand, interpret and criticize all kinds of information in the media. It is the knowledge, skills and abilities that people use the media information for personal life and social development. In brief, it is the ability of people to acquire, analyze, spread and use various forms of media messages. Media literacy is not only a process that helps people to understand the media and use the media, but also a means to help people with the characteristics of the media, communication skills and effects [1].

In 1990s, Chinese scholars published a series of translation articles on Western media literacy. After more than 20 years of development, the establishment of the legitimacy and necessity of media literacy has been preliminarily completed. However, the practical activities of media literacy research are relatively scattered and lack of top-level design, which has seriously limited the practice transformation of the research [2].

Improving the media literacy of college students and innovating the media literacy education of College Students is an objective need to promote the all-round development of college students. And it is also the practical need and the important content of Ideological and political work in Colleges and universities.

\section{The Present Situation of Chinese College Students' Media Literacy}

Data shows that as of June 2016, Chinese internet users reached 710 million and internet penetration rate rose to $51.7 \%$. The most equipment online is the mobile phone. The proportion of student groups accounted for $46.4 \%$ in the new Internet users. The purpose of this part of the population using the Internet is mainly entertainment and communication. Portable smart phones are better able to meet their needs [3].

\subsection{Status of the Media Contact}

Into the Web 2.0 era, the media contact activities basing on the network have become the most popular media activity of contemporary Chinese College Students. Entertainment, social communication and access to information have become the main motive of college students' media contact. As a result of multiple attraction, college students in the use of new media showed the tendency of entertainment, fragmentation and surface. 


\subsection{Media Awareness}

In today's world, the new media is the main window for college students to know and understand the world. According to the concept and experience of the Internet, the college students understand the environment in which most of them can detect this change in time and change their own way of thinking and action. However, due to the lack of systematic theoretical knowledge and practical training, most of the college students' knowledge about the media is mostly based on perceptual knowledge and experience, which is not comprehensive, systematic and thorough. As a result, they use the media to influence others less in this way and there is still much room for improvement in media participation and supervision.

\subsection{Media Ability}

The emergence of new media had met the needs of the public for the microphone in the era of loud noise. However, the diversity of sound inevitably mixed with noise and a lot of redundant information. Media reflection ability is embodied in the ability to think about the deep sense of media content, the relationship between media and society, and the relationship between media and audience. Those who have a good quality of thinking and reflection of college students are still a minority, the majority of students still need to further improve the ability to reflect.

\subsection{Self - cognition of Media Literacy}

Media literacy education and media development are not synchronized in China. College students are vague about media literacy and they also generally recognize the impact of media literacy. It is very necessary to carry out media literacy education in the basic theory of media literacy among college students.

\section{Causes of Media Literacy Deficiency of Chinese College Students}

\subsection{Media Ecology}

George Gerbner, the founder of Cultivation Theory, suggested that modern people were living in the media of civilization from the cradle to the grave and this effect went deep into the bone marrow [4]. The new media is changing people's way of life in all aspects, shaping people's mental outlook, affecting their way of thinking and behavior habits. At present, China is in a period of social transformation and the media ecology has been reconstructed with the advent and rapid development of the Internet, mobile phones, microblogging, WeChat and other new media, which is the starting point of the media literacy education for college students.

The modern media especially the electronic media are fast, convenient, vivid, entertaining and rich in content in the era of mobile Internet. Client, WeChat, micro-blog and other tools output information to the user at all times, which greatly expands the time for the audience to contact the media, extends the time of contact with the media and floods modern people into massive amounts of information. The massive information brings about the diversity of values, leading to the students encounter thoughts confused who are in the period of the formation of the outlook on life values. At the same time, college students spend a lot of time and energy on exposure to the media. They are easy to meet the passive knowledge accumulation. Therefore, their enthusiasm to participate in social practice has been greatly reduced and the social action ability and reflective ability are correspondingly reduced.

The media economy is an eyeball economy that must be profitable by winning the audience's attention. In the late $90 \mathrm{~s}$ of last century, China's mass media embarked on the road of collectivization. After joining the WTO, foreign media had been stationed in China and all kinds of media competition had intensified. The commercial and market-oriented operating mechanism led to a lot of media to pursue the click rate blindly for their own survival and development. The media appeared the cultural tendency of superficiality, entertainment and vulgarization. College students lack understanding of the media structure characteristics. The concept of social reality of college students is affected by the media content, which seriously reduces the spiritual taste and cultural accomplishment.

Media convergence is the dominant trend of media development, which refers to the integration of various types of new media content into a new, fully integrated and interactive media form [5]. The idea of rapid propagation in the form of melted media is spread exponentially, just like the spread of bacteria in living organisms. The characteristics of virus transmission greatly accelerated the process of spreading rumors, making it harder to discern the authenticity of the information. Many of the ideas that have been widely disseminated in the online world are mistaken for truth. Even if there are facts that proved to be clearly wrong, a lot of people still believe it is true. This requires that college students not only have the ability to understand, absorb and utilize the media information, but also have the ability to choose and question the media information. College students need to pick out the important and valuable things from the noise that makes us notice and react.

\subsection{College Students' Own Factors}

Nowadays college students are called "digital natives", who are the first generation of digital technology and the Internet world to grow up and most of the time to keep in touch with the network [6]. Generally speaking, the special group characteristics of college students are the important reasons for their lack of media literacy.

First of all, college students need to improve their selfcontrol ability. During the university period, college students are in the golden age of personality molding whose independence and autonomy in learning, living and communicating with others are stronger than ever before. 
However, because of the limitation of age, knowledge and experience, the college students who are in the process of growing up will not be able to make an objective and comprehensive evaluation of things independently. Their self-control ability is weak. Once exposed to the media, they are easily attracted by the media and become over-obsessed and dependent. College students are the recipients of media information, not analysts, judges and critics. As Neil Postman points out, the way of thinking in the printing age is rigorous, rational and logical, and the way of thinking in the television age has begun to be fragmented, logical and entertaining, to the new era dominated by the Internet and mobile phones, the public indulge in the entertainment of modern science and technology and their ability to perceive self-contradiction is lost. College students spend a lot of time in the media to provide a wide variety of information. Their way of thinking depends on the medium of expression, so their ability to think and criticize is impaired and their media literacy is relatively low.

Secondly, the knowledge structure of college students should be strengthened. There are four kinds of information into the human body. One is the cognitive information which exists in the human brain. The second is the emotional information which exists in the heart. The third is the aesthetic information which exists in the eyes and ears. The fourth, it is the moral information which exists in the human spirit. Good media literacy is based on a complete knowledge structure while these four kinds of information are indispensable in the complete knowledge structure [6]. The needs of the audience contain the media literacy, while the media literacy limit the audience's literacy. College students are in the second psychological heartbroken and self-discovery period. Due to the different regions and cultural backgrounds, and influenced by the traditional way of thinking, the concept of education and employment pressure, college students generally pay more attention to the professional knowledge and practical knowledge and despise basic knowledge and humanistic knowledge. Therefore, the scientific spirit and humanistic feelings of college students are separated, and the knowledge structure is not incomplete. To some extent, this bias affects their level of appreciating media products and prevents them from acquiring enduring happiness about awareness, emotion, aesthetics, morality, and so on through media channels.

\section{Countermeasures and Suggestions on Improving College Students' Media Literacy}

Colleges and universities are the main position and main channel of media literacy education. Based on the current situation of College Students' media literacy and considering the reasons for the lack of media literacy, the author puts forward some suggestions from the University level.

\subsection{Team Building}

A high level of teacher staff is the key to improve the level of media literacy education. Only by improving the ability of teachers, the level and effect of media literacy education can be improved. At present, there are not specialized teachers for media literacy in China and it is imminent to speed up media literacy teacher training. Therefore, colleges and universities must increase investment to build a high quality teachers team through various ways of training [7].

In the universities with news major, the news full-time teachers can be competent for the teaching task of media literacy education. It is weak to carry out the media literacy of the whole school level. The university can fully mobilize the news professional teachers for training teachers with relevant knowledge background to expand the coverage of the media literacy education of teachers. In the absence of news professional universities, various forms of on-the-job training can be carried out to improve the media literacy of professional teachers, so that they can integrate the media literacy education contents into the subject teaching. On the other hand, colleges and universities can fully mobilize social resources to assist the media literacy education through lectures, seminars and professional knowledge training. In addition, it can also enhance the media literacy of teachers who often communicate with college students, so that Media literacy education and ideological work can be organically integrated. Educators must combine the reality of the school and the reality of the media and strengthen the research work of the relevant theory to guide the new media literacy education under the environment of the new educational concepts and educational model.

\subsection{Student Aspect}

College students are the center of media literacy education. College students are fully engaged in the participation consciousness and subjective initiative, which is the guarantee of the media literacy education. College students can consciously strengthen self-learning to enhance the media awareness and improve the ability to use and criticize the media. On the other hand, college students can also strengthen their own moral training, maintain a good value orientation, develop a good media contact habits and cultivate the aesthetic level. In the end, college students can become active controllers of the media, rather than passive recipients of media communication.

Media literacy is a new educational theory, but also a teaching practice. Students' practical cognitive ability should be paid more attention to in the process of education. Colleges and universities can take advantage of the rich campus media resources and joint social media resources. In addition, colleges and universities can also provide the platform and position for students to engage and participate in media practice. Colleges and universities generally have a radio station, a television station, a university newspaper, a network center and other media. Through these campus media, colleges and universities can hold the micro-film 
contest, the network culture festival, the classic film show and so on. College students take part in various forms of media practice, in which they can understand the process of newspaper, radio, television media production and communication. Schools can also regularly invite host, editors, journalists, announcer, director, etc who are from the social media. College student know the freshest information from the first line and know the whole process of media information production through such face-to-face communication. This helps to eliminate the sense of mystery and vague about the media and helps students keep more scientific, rational and objective view of the media content.

\subsection{Atmosphere Construction}

Global media literacy education is moving towards the path to rationalization. Countries such as Britain, Canada, Australia, Japan and South Korea have all added media literacy to the national education system [9]. Many governments have promoted the media literacy education to a strategic policy level that enhances national competitiveness and the national overall quality. However, in China, the media literacy education is still a new subject, far less attention than traditional subjects. There is a process of gradual recognition for media literacy to enter college. This requires schools to continuously build the campus culture media about media literacy education so that more college students are able to change their ideas and identify media literacy education. Campus cultural environment is the cultural field which is the most closely connected with the college students. It has an internalization on college students. Colleges and universities can make full use of campus media to create a good cultural environment about media literacy education. The campus media has inherent advantages such as wide coverage, high frequency, good effect. Colleges and universities can make full use of the campus media to disseminate the media knowledge, skill and idea in the new media era and carry out effective and comprehensive education. Colleges and universities can forwardly set up issues and carry out activities such as ideological discussions, understanding confrontation and good experience show about media literacy education. By creating the campus atmosphere and environment, the misunderstanding of College Students' media literacy education is reversed.

\subsection{Multi Resultant}

Media literacy education is a social system project that requires concerted efforts by the whole society. Media literacy education is a part of college education. However, in addition to school education, social media workers, media professionals and parents of students all play an important role in media literacy education. The "four in one" education system formed by the government, the society, the family and the school can promote the socialization of media literacy education.

Government departments should appeal to the community to support the media literacy education in different forms. As the users of public resources, the media should strengthen the sense of responsibility and build the public platform for college students' media literacy education. Family is the first class for children to grow which should take the important role of media literacy education. Colleges and universities need to actively strengthen ties and strive to participate in media literacy education. Government's support is the backing. School education is the main body. Family, media and social forces participate together. Only by constructing this system can we promote the diversified and healthy development of College Students' Media Literacy Education.

\section{Conclusion}

Media literacy is the result and accomplishment of a training process [10]. The ultimate goal of media literacy is not to teach people to be skilled media consumers, but to cultivate more mature and rational citizens. In the internet age, the new media has dominated university campuses with a strong spread advantage. While the new media brings about huge amounts of information, it also puts forward high requirements for college students' media literacy. As the main position and main channel of media literacy education, colleges and universities should actively and effectively carry out media literacy education. To make comprehensive use of educational measures, to build a comprehensive education network and to form an efficient and reasonable pattern of Education, Colleges and universities can effectively improve students' media literacy so that they can use the media to improve and develop themselves and promote their overall development.

\section{References}

[1] Zhang Kai. Media literacy education in the information age [J]. Modern communication, 2003, 1:100.

[2] Zhang Yuexin. The research perspective and present situation of media literacy in China [J]. News and Writing, 2017,6:9.

[3] China Internet Network Information Center. The thirty-eighth China Internet Development Statistics Report [OL]. http://www.cnnic.cn/gywm/xwzx/rdxw/2016/201608/t201608 03_54389.htm

[4] Duan Jinju. Generalization of network communication channel and media literacy education of College Students [J]. Journal of Neijiang Normal University, 2011, 26:106.

[5] Charles Sterin. The Media is The Message [M]. Beijing: Renmin University of China Press, 2014:180.

[6] Charles Sterin. The Media is The Message [M]. Beijing: Renmin University of China Press, 2014:92.

[7] Zhang Kai. Introduction to Media Literacy [M]. Beijing: China Communication University Press, 2006:103.

[8] Li Junlin. Media Literacy in the Information Age [M]. Changsha: Hunan People's Press, 2010:15.

[9] Zhang Kai. Introduction to Media Literacy [M]. Beijing: China Communication University Press, 2006:76.

[10] Zhang Kai. Discussion on the establishment of media literacy discipline [J]. Modern communication, 2016, 1:144. 